\title{
ANALISIS RISIKO GEMPABUMI DI CILACAP PROVINSI JAWA TENGAH
}

\section{Earthquake Risk Analysis in Cilacap, Central Java Province}

\author{
Muhaimin ${ }^{1)^{*}}$, Boedi Tjahjono2), dan Darmawan ${ }^{2)}$ \\ 1) Alumni Program Studi Mitigasi Bencana dan Kerusakan Lahan, Sekolah Pascasarjana, Institut Pertanian Bogor, \\ Kampus IPB Dramaga, Bogor 16680 \\ ${ }^{2)}$ Departemen Ilmu Tanah dan Sumberdaya Lahan, Fakultas Pertanian IPB, Jl. Meranti Kampus IPB Dramaga, \\ Bogor 16680
}

\begin{abstract}
Earthquake is an event that occur suddently and still unpredictable untill now. The area surrounding subduction zone is normally susceptible to earthquake disasters, such as Cilacap Regency located at the southern coast of Java Island. Tasikmalaya's earthquake, occurred on 2 September 2009 with a magnitude of M 7.3, for instance, have had a great impact on Cilacap Regency. Accordingly, study on earthquakes risk for Cilacap Regency will be indispensable. The study of earthquake hazard and vulnerability will support the risk assessment and mitigation. This research aims to analysis and mapping the earthquake hazard zone, vulnerability, and risk of Cilacap areas. The method for analysing earthquake hazard used the value of peak ground acceleration at surface $\left(P G A_{M}\right)$ derived from probabilistic methods, while the value of vulnerability was determined based on the type of land use (by scoring), as for the risk calculation used an equation of $R=H \times V$. The results indicated that the entire of Cilacap City was classified into moderate hazard class under the PGA $A_{M}$ value varies from $0.405 \mathrm{~g}$ to $0.494 \mathrm{~g}$. While the land use of settlement possessed a high class of vulnerability that covered the villages of Tambakreja, Sidanegara, Donan, southern part of Tritih Kulon, Cilacap, Mertasinga, and Kamulyan. As for risk analysis showed that the higest class of risk covers an area of 3,237.40 ha covering the villages of Lomanis, Tambakreja, Tritih Kulon, Sidanegara, Donan, Mertasinga, and Cilacap. Consequently, these villages need attention and priority in future disaster mitigation programs.
\end{abstract}

Keywords: Cilacap, earthquake risk, peak ground acceleration at surface, probabilistic method

\begin{abstract}
ABSTRAK
Gempabumi merupakan kejadian yang datangnya secara tiba-tiba. Hingga kini kejadian gempa bumi tersebut masih belum dapat diprediksi kedatangannya. Wilayah yang berdekatan dengan jalur subduksi pada umumnya merupakan wilayah yang rawan terhadap bencana gempabumi, seperti Kabupaten Cilacap yang berada di pesisir selatan Pulau Jawa. Gempabumi Tasikmalaya yang terjadi tanggal 2 September 2009, dengan magnitudo M 7.3 terbukti telah berdampak besar terhadap wilayah Kabupaten Cilacap. Hal ini yang membuat perlunya penelitian risiko gempabumi di wilayah Cilacap. Studi bahaya gempabumi dan kerentanan akan sangat mendukung untuk penilaian risiko maupun program mitigasi. Penelitian ini bertujuan untuk melakukan analisis dan pemetaan bahaya, kerentanan, dan risiko gempabumi di kota Cilacap. Metode untuk analisis bahaya gempabumi menggunakan nilai percepatan tanah maksimum di permukaan $\left(P G A_{M}\right)$ dari hasil metode probabilistik. Untuk kerentanan gempabumi ditentukan berdasarkan jenis penggunaan lahan. Adapun untuk perhitungan risiko bencana gempabumi digunakan persamaan $\mathrm{R}=\mathrm{H} \times \mathrm{V}$. Berdasarkan hasil analisis bahaya, didapatkan bahwa seluruh Kota Cilacap tergolong ke dalam kelas bahaya sedang dengan nilai $P G A_{M}$ bervariasi dari $0.405-0.494$ gal. Berdasarkan hasil analisis kerentanan, diperoleh bahwa kerentanan tinggi terdapat di penggunaan lahan permukiman yang meliputi Desa-desa Tambakreja, Sidanegara, Donan, Tritih Kulon bagian selatan, Cilacap, Mertasinga, dan Kamulyan. Adapun hasil analisis risiko menunjukkan bahwa kelas risiko tinggi di daerah penelitian meliputi area seluas 3,237.40 ha yang terdapat di Desa-desa Lomanis, Tambakreja, Tritih Kulon, Sidanegara, Donan, Mertasinga, dan Cilacap, sehingga di desa-desa tersebut perlu mendapat perhatian dan prioritas untuk program mitigasi bencana ke depan.
\end{abstract}

Kata kunci: Kota Cilacap, risiko gempabumi, percepatan tanah maksimum di permukaan, metode probabilistik

\section{PENDAHULUAN}

Cilacap bagian kota berada di wilayah pesisir selatan Jawa Tengah yang terletak secara geomorfologis di dataran pantai berpasir, seperti gumuk pasir maupun beting gisik, dan sebagian berada di dataran fluvial Sungai Serayu (Hadisumarno et al., 1982; Verstappen, 2000). Wilayah ini berhadapan langsung dengan zona subduksi Jawa, yaitu subduksi antara Lempeng Indo-Australia dan Lempeng Eurasia di Samudera Hindia. Selain itu secara geologis wilayah Cilacap juga berada dekat dengan jalur Sesar Pamanukan-Cilacap (Djuri, 1975; Satyana, 2007 dalam Nguyen et al., 2015), sehingga kondisi ini menyebabkan Cilacap sering terpengaruh oleh guncangan gempabumi 
yang dapat menimbulkan bencana. Salah satu gempabumi yang menimbulkan bencana di Cilacap adalah gempabumi Tasikmalaya yang terjadi pada tanggal 2 September 2009. Gempabumi ini mempunyai magnitudo 7.3 dan kedalaman 30 km (BMKG, 2009) yang telah merusak lebih dari 1,000 rumah di sebagian wilayah Kabupaten Cilacap dan menjadikan 2,388 orang menjadi pengungsi (BNPB, 2009).

Bencana gempabumi terjadi sebagian besar justru diakibatkan oleh adanya kerusakan konstruksi bangunan dan non bangunan. Gempabumi juga menyebabkan bencana ikutan, seperti kebakaran, kecelakaan industri, dan transportasi. Cilacap bagian kota sebagai pusat pemerintahan dan ekonomi di Kabupaten Cilacap memiliki kawasan permukiman padat dengan jumlah penduduk sebesar 233,463 jiwa (BPS, 2014) serta sarana-prasarana penting seperti kantor pemerintahan, Pertamina Refinery Unit IV Cilacap, Pembangkit Listrik Tenaga Uap Karang Kandri, dan Bandar Udara Tunggul Wulung. Namun demikian permukiman dan sarana-prasarana yang dibangun di Cilacap seringkali tidak didesain sesuai dengan standar bangunan tahan gempabumi. Oleh karena itu bisa tergambarkan bagaimana besarnya bencana yang dapat ditimbulkan di masa lalu oleh guncangan gempabumi yang besar yang terjadi di daerah ini. Seperti kita ketahui bahwa bahaya gempabumi tidak bisa dihindarkan, meskipun demikian dampaknya tentu dapat diantisipasi dan dikurangi melalui kegiatan mitigasi bencana gempabumi. Melihat kenyataan bahwa daerah penelitian merupakan salah satu daerah yang rawan terhadap bencana gempabumi, maka upaya mitigasi sangat diperlukan di antaranya melalui studi tentang bahaya, kerentanan, dan risiko gempabumi.

Penelitian ini mengambil lokasi di Cilacap bagian kota dengan tujuan untuk melakukan analisis dan pemetaan terhadap bahaya gempabumi, kerentaan, serta risiko gempabumi. Kelebihan utama dari penelitian ini adalah bahwa peta bahaya gempabumi yang dihasilkan sudah menggambarkan besarnya guncangan tanah di permukaan yang direpresentasikan oleh nilai percepatan maksimum permukaan tanah $\left(P G A_{M}\right)$. Nilai $P G A_{M}$ diperoleh dari perhitungan secara empiris berdasarkan informasi sumber gempabumi dan kondisi geologi setempat melalui pendekatan probabilistik (probabilistic seismic hazard analysis atau PSHA). Pendekatan ini dikembangkan oleh Cornel pada tahun 1968 dan banyak digunakan hingga kini (Wang, 2003). PSHA adalah formulasi matematis yang berasal dari analisis probabilitas hubungan statistik antara besarnya gempabumi, lokasi, dan redaman gerakan tanah (Wang, 2012). PSHA dapat menentukan frekuensi total yang melebihi berbagai tingkat gerakan tanah selama periode waktu tertentu (Sokolov dan Ismail-Zadeh, 2015), sehingga pendekatan ini dapat digunakan untuk menghitung bahaya gempabumi berdasarkan pada kumpulan kejadian gempabumi (McGuire, 1995). Untuk bahaya seismik pendekatan ini diakui lebih baik daripada pendekatan deterministik (Mualchin, 2010). Alasan pendekatan probabilistik digunakan dalam penelitian ini karena kerusakan bangunan akibat guncangan tanah tergantung pada besarnya kekuatan gempabumi, jarak terhadap pusat gempabumi, dan kondisi geologi daerah setempat. Informasi tentang besarnya guncangan tanah ini juga dapat dipakai untuk mendesain bangunan yang tahan gempabumi agar bangunan tidak mengalami kerusakan apabila mengalami guncangan dengan nilai $P G A_{M}$ yang diperkirakan tersebut.

Berdasarkann Peta Gempabumi Indonesia 2010 yang dibuat oleh Kementerian Pekerjaan Umum, tercatat bahwa daerah penelitian memiliki nilai PGA antara $0.4-$ 0.5 g. Nilai PGA ini masih merupakan nilai percepatan tanah maksimum di batuan dasar, sehingga belum mencerminkan besarnya guncangan tanah yang sesungguhnya di permukaan yang terdapat banyak bangunan serta penduduk yang tinggal di dalamnya. Hasil penelitian ini diharapkan akan sangat bermanfaat untuk pengetahuan masyarakat dan pemahaman tentang gempabumi serta dampaknya, dan dapat dijadikan sebagai acuan dalam kegiatan mitigasi bencana gempabumi di Cilacap bagian kota.

\section{BAHAN DAN METODE}

Lokasi penelitian mencakup wilayah Kota Cilacap yang terletak di bagian selatan Kabupaten Cilacap, Provinsi Jawa Tengah. Wilayah ini secara geografis berada di antara $7^{\circ} 38^{\prime} 00^{\prime \prime}-7^{\circ} 45^{\prime} 00^{\prime \prime}$ Lintang Selatan dan $109^{\circ}$ 00’ 00" - $109^{\circ} 07^{\prime}$ 00” Bujur Timur (Gambar 1). Lokasi penelitian terbentang seluas 7,180 ha yang meliputi seluruh wilayah desa di Kecamatan-kecamatan Cilacap Selatan, Cilacap Tengah, Cilacap Utara, Kecamatan Kesugihan (hanya 2 desa, yaitu Desa Menganti dan Karang Kandri), dan Kecamatan Jeruk Legi (hanya 1 desa, yaitu Desa Tritih Lor). Bahan penelitian yang digunakan antara lain adalah literatur tentang kondisi geologi dan tektonik, katalog gempabumi (BMKG, 2015), data $\mathrm{Vs}^{30}$, Peta Rupa Bumi Indonesia (RBI) Kabupaten Cilacap skala 1:50,000, dan data citra yang diambil dari Google Earth.

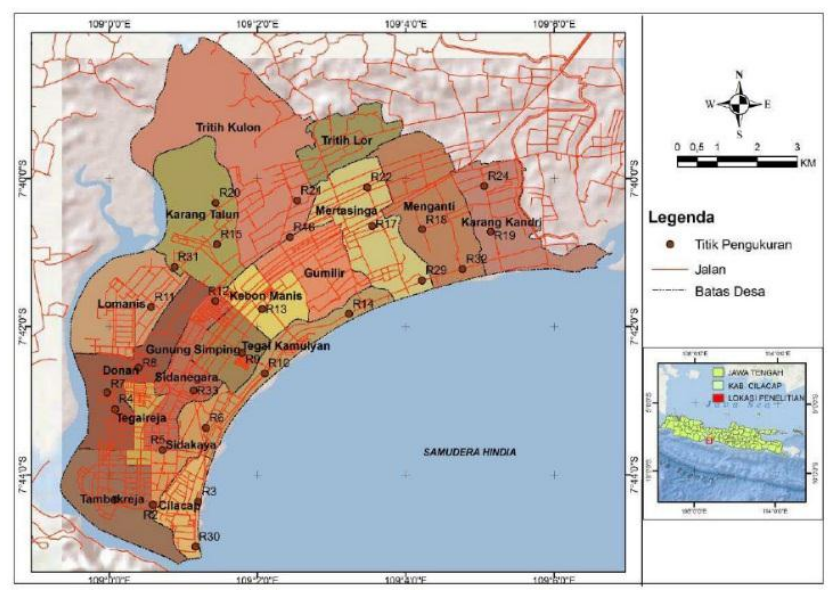

Gambar 1. Lokasi penelitian

\section{Analisis dan Pemetaan Bahaya (Hazard) Gempabumi di Kota Cilacap}

Bahaya utama gempabumi pada dasarnya adalah guncangan atau gerakan tanah yang menimbulkan gangguan atau kerusakan terhadap struktur bangunan, gedung, sarana prasarana, harta benda, orang, dan lingkungan. Besaran guncangan tanah ini dapat direpresentasikan dengan nilai percepatan maksimum di permukaan tanah (peak ground acceleration at surface 
atau $P G A_{M}$ ). Dalam hal ini semakin besar nilai $P G A_{M}$, maka semakin besar pula bahaya gempabumi yang mungkin terjadi. Analisis bahaya gempabumi dalam penelitian ini dilakukan dengan menghitung nilai $P G A_{M}$ melalui persamaan berikut (BSN, 2012):

$$
P G A_{M}=F_{P G A} \times P G A
$$

dengan $P G A_{M}$ adalah nilai percepatan maksimum di permukaan tanah; PGA adalah nilai percepatan maksimum di batuan dasar; dan $F_{P G A}$ adalah koefisien situs untuk PGA. Untuk nilai koefisien situs dalam penelitian ini mengacu pada ketentuan SNI 1726-2012 (Tabel 1) yang hasilnya tergantung pada hasil klasifikasi situs tanah (Tabel 2). Sebelum dilakukan perhitungan nilai $P G A_{M}$ (sesuai persamaan 1) maka perlu dilakukan terlebih dahulu perhitungan untuk nilai PGA dan klasifikasi situs tanah yang akan diuraikan sebagai berikut:

\section{Perhitungan Nilai Percepatan Maksimum di Batuan Dasar (PGA)}

Perhitungan nilai PGA dilakukan dengan metode probabilistic (Probabilistic Seismic Hazard Analysis atau PSHA) dengan menghitung ancaman gempabumi berdasarkan pada kumpulan hasil dari semua kejadian gempabumi dan gerak tanah yang mungkin dapat terjadi di masa yang akan datang. Metode probabilistik memiliki 6 tahapan yaitu (1) pengumpulan dan pengolahan data gempabumi, (2) pemodelan sumber gempabumi, (3) karakterisasi sumber gempabumi, (4) fungsi atenuasi, (5) logic tree, dan (6) analisis seismic hazard dengan menggunakan Teorema Probabilitas Total berdasarkan persamaan berikut (Cornell, 1968 dalam Sunardi dan Nugraha, 2015).

$$
P_{x}(x)=\int_{M} \int_{R} P(X>x \mid m, r) f_{M}(m) f_{R}(r) d r d m
$$

dimana $P_{x}(x)$ adalah probabilitas sebuah gempabumi dengan magnitudo $\mathrm{m}$ dan jarak $\mathrm{r}$ yang menghasilkan percepatan puncak $\mathrm{X}$ di lokasi lebih tinggi dari $x ; f_{M}$ dan $f_{R}$ berturut-turut adalah fungsi distribusi dari magnitudo dan jarak.

Dalam hal ini analisis hazard gempa dilakukan untuk probabilitas terlampaui $2 \%$ dalam 50 tahun (peluang terjadinya gempabumi dalam rentang waktu 50 tahun dengan kekuatan yang melampaui nilai percepatan maksimum sebesar 2\%) atau setara dengan periode ulang gempabumi 2,475 tahun sesuai ketentuan SNI 1726-2012.

\section{Klasifikasi Situs Tanah}

Tanah dalam penelitian ini didefinisikan sebagai lapisan permukaan Bumi yang memiliki kecepatan rambat gelombang geser (Vs) kurang dari $750 \mathrm{~m} \operatorname{detik}^{-1}$. Klasifikasi situs tanah berdasarkan Peraturan Gempabumi Indonesia (SNI 1726-2012) ditentukan antara lain berdasarkan kecepatan rambat gelombang geser rata-rata pada kedalaman 0-30 m (nilai $V s^{30}$ ) seperti terlihat dalam Tabel 2. Nilai kecepatan rambat gelombang geser dihitung sampai kedalaman tidak lebih dari $30 \mathrm{~m}\left(V^{30}\right)$ karena berdasarkan pada berbagai penelitian didapatkan bahwa hanya lapisan setebal $30 \mathrm{~m}$ paling atas yang menentukan pembesaran gerakan tanah di permukaan. Dalam penelitian ini untuk klasifikasi situs tanah daerah penelitian menggunakan data $V s^{30}$ dari PUSLITBANG BMKG dari sebanyak 31 titik pengukuran (titik R1 hingga R33) yang tersebar di daerah penelitian (Gambar 1 dan Tabel 3). Titik-titik lokasi $V s^{30}$ ditentukan berdasarkan sistem grid yang dimodifikasi sesuai dengan kondisi lapangan.

Hasil analisis bahaya gempabumi kemudian dipetakan dengan metode interpolasi Inverse Distance Weighted (IDW) melalui piranti lunak ArcGis 10.2. Dalam penelitian ini, tingkat bahaya gempabumi ditentukan berdasarkan kriteria kelas yang telah disusun, yaitu bahaya rendah dengan nilai $P G A_{M}<167$ gal, bahaya sedang dengan nilai $P G A_{M}$ antara 168 - 564 gal, dan bahaya tinggi dengan kriteria nilai $P G A_{M}>564$ gal sesuai Tabel 4 (BMKG, 2015).

Tabel 1. Koefisien situs untuk PGA $\left(F_{P G A}\right)($ SNI-1726-2012)

\begin{tabular}{lccccc}
\hline \multicolumn{1}{c}{ Kelas Situs } & $\begin{array}{c}\text { PGA } \leq \\
0.1\end{array}$ & $\begin{array}{c}\text { PGA }= \\
0.2\end{array}$ & $\begin{array}{c}\text { PGA }= \\
0.3\end{array}$ & $\begin{array}{c}\text { PGA }= \\
0.4\end{array}$ & $\begin{array}{c}\text { PGA } \geq \\
0.5\end{array}$ \\
\hline $\begin{array}{l}\text { SA (Batuan } \\
\text { Keras) }\end{array}$ & 0.8 & 0.8 & 0.8 & 0.8 & 0.8 \\
$\begin{array}{l}\text { SB (Batuan) } \\
\text { SC (Tanah }\end{array}$ & 1.0 & 1.0 & 1.0 & 1.0 & 1.0 \\
$\begin{array}{l}\text { keras) } \\
\text { SD (Tanah } \\
\text { sedang) }\end{array}$ & 1.2 & 1.2 & 1.1 & 1.0 & 1.0 \\
$\begin{array}{l}\text { SE (Tanah } \\
\text { lunak) }\end{array}$ & 1.6 & 1.4 & 1.2 & 1.1 & 1.0 \\
$\begin{array}{l}\text { SF (Tanah } \\
\text { khusus) }\end{array}$ & 2.5 & 1.7 & 1.2 & 0.9 & 0.9 \\
\hline Keterangan : SS & $\mathrm{SS}$ & $\mathrm{SS}$ & $\mathrm{SS}$ & $\mathrm{SS}$ & $\mathrm{SS}$ \\
\hline
\end{tabular}

Keterangan : SS adalah lokasi yang memerlukan investigasi geoteknik

Tabel 2. Klasifikasi situs tanah berdasarkan nilai $V s^{30}$ sesuai SNI 1726-2012

\begin{tabular}{lc}
\hline \multicolumn{1}{c}{ Kelas Situs } & Vs $\left(\mathbf{m ~ d t}^{-\mathbf{1}}\right)$ \\
\hline SA (Batuan Keras) & $>1500$ \\
SB (Batuan) & $750-1500$ \\
SC (Tanah keras) & $350-750$ \\
SD (Tanah sedang) & $175-350$ \\
SE (Tanah lunak) & $<175$ \\
SF (Tanah khusus) & Membutuhkan penyelidikan geoteknik dan \\
\hline
\end{tabular}

\section{Analisis dan Pemetaan Kerentanan (Vulnerability) Gempabumi di Kota Cilacap}

Kerentanan adalah suatu kondisi dari suatu komunitas atau masyarakat yang mengarah atau menyebabkan ketidak-mampuan dalam menghadapi suatu ancaman bencana (BNPB, 2012). Atau dapat pula digambarkan sebagai kecenderungan dari elemen-elemen yang terekspose bahaya, seperti manusia, mata pencaharian, atau aset, sehingga elemen-elemen tersebut dapat menanggung kerugian ketika terkena peristiwa bahaya (Cardona et al., 2012). Pengertian tersebut menunjukkan bahwa semakin tinggi tingkat kerentanan, maka potensi bencana akan semakin tinggi. Dalam kasus gempabumi, kerentanan lebih ditentukan oleh ketahanan konstruksi bangunan dalam merespon gempabumi yang terjadi, karena kebanyakan terjadinya korban disebabkan oleh runtuhnya bangunan. Oleh karena itu, kerentanan 
gempabumi dalam hal ini direpresentasikan pada kekuatan bangunan dan dapat dicerminkan dari penggunaan lahannya. Dengan asumsi bahwa bangunan di daerah penelitian tidak didesain tahan terhadap gempabumi, maka penggunaan lahan yang mempunyai jumlah bangunan yang banyak akan lebih rentan dibandingkan dengan daerah yang memiliki bangunan yang lebih sedikit jumlahnya. Dengan alasan tersebut, maka untuk mengukur tingkat kerentanan dalam penelitian ini digunakan kriteria yang mengacu pada jenis penggunaan lahan sebagai berikut: kerentanan rendah (lahan tidak terbangun), kerentanan sedang (lahan industri), dan kerentanan tinggi (lahan permukiman). Peta penggunaan lahan yang digunakan mempunyai skala 1:10,000 yang diturunkan dari interpretasi citra satelit di Google Earth.

Tabel 3. Data $V s^{30}$, kelas situs, $P G A, F_{P G A}$, dan $P G A_{M}$

\begin{tabular}{|c|c|c|c|c|c|c|c|c|}
\hline No. & Titik & Lon & Lat & VS30 & Kelas Situs & PGA & FPGA & PGAm \\
\hline 1 & $\mathrm{R} 1$ & 109.00115 & -7.73898 & 179 & Tanah Sedang & 0.466 & 1.0 & 0.466 \\
\hline 2 & $\mathrm{R} 2$ & 109.00980 & -7.74014 & 203 & Tanah Sedang & 0.466 & 1.0 & 0.466 \\
\hline 3 & $\mathrm{R} 3$ & 109.01997 & -7.73945 & 212 & Tanah Sedang & 0.465 & 1.0 & 0.465 \\
\hline 4 & $\mathrm{R} 4$ & 109.00127 & -7.71863 & 221 & Tanah Sedang & 0.463 & 1.0 & 0.463 \\
\hline 5 & R5 & 109.01191 & -7.72780 & 211 & Tanah Sedang & 0.464 & 1.0 & 0.464 \\
\hline 6 & R6 & 109.02168 & -7.72282 & 197 & Tanah Sedang & 0.463 & 1.0 & 0.463 \\
\hline 7 & R7 & 108.99948 & -7.71484 & 203 & Tanah Sedang & 0.463 & 1.0 & 0.463 \\
\hline 8 & $\mathrm{R} 8$ & 109.00655 & -7.70928 & 225 & Tanah Sedang & 0.462 & 1.0 & 0.462 \\
\hline 9 & R9 & 109.02982 & -7.70595 & 185 & Tanah Sedang & 0.462 & 1.0 & 0.462 \\
\hline 10 & $\mathrm{R} 10$ & 109.03494 & -7.71053 & 217 & Tanah Sedang & 0.462 & 1.0 & 0.462 \\
\hline 11 & $\mathrm{R} 11$ & 109.00939 & -7.69566 & 211 & Tanah Sedang & 0.462 & 1.0 & 0.462 \\
\hline 12 & $\mathrm{R} 12$ & 109.02387 & -7.69432 & 197 & Tanah Sedang & 0.459 & 1.0 & 0.459 \\
\hline 13 & $\mathrm{R} 13$ & 109.03432 & -7.69610 & 193 & Tanah Sedang & 0.457 & 1.0 & 0.457 \\
\hline 14 & $\mathrm{R} 14$ & 109.05388 & -7.69718 & 207 & Tanah Sedang & 0.453 & 1.0 & 0.453 \\
\hline 15 & $\mathrm{R} 15$ & 109.02419 & -7.68153 & 193 & Tanah Sedang & 0.458 & 1.0 & 0.458 \\
\hline 16 & $\mathrm{R} 16$ & 109.04060 & -7.67994 & 190 & Tanah Sedang & 0.454 & 1.0 & 0.454 \\
\hline 17 & $\mathrm{R} 17$ & 109.05907 & -7.67739 & 192 & Tanah Sedang & 0.451 & 1.0 & 0.451 \\
\hline 18 & $\mathrm{R} 18$ & 109.07035 & -7.67817 & 160 & Tanah Lunak & 0.450 & 0.9 & 0.405 \\
\hline 19 & $\mathrm{R} 19$ & 109.08570 & -7.67871 & 172 & Tanah Lunak & 0.450 & 0.9 & 0.405 \\
\hline 20 & $\mathrm{R} 20$ & 109.02391 & -7.67224 & 153 & Tanah Lunak & 0.456 & 0.9 & 0.410 \\
\hline 21 & $\mathrm{R} 21$ & 109.04222 & -7.67171 & 193 & Tanah Sedang & 0.453 & 1.0 & 0.453 \\
\hline 22 & $\mathrm{R} 22$ & 109.05798 & -7.66872 & 190 & Tanah Sedang & 0.450 & 1.0 & 0.450 \\
\hline 23 & $\mathrm{R} 24$ & 109.08430 & -7.66843 & 203 & Tanah Sedang & 0.449 & 1.0 & 0.449 \\
\hline 24 & $\mathrm{R} 25$ & 109.03996 & -7.64885 & 355 & Tanah Padat & 0.450 & 1.0 & 0.450 \\
\hline 25 & $\mathrm{R} 26$ & 109.03545 & -7.62927 & 282 & Tanah Sedang & 0.447 & 1.0 & 0.447 \\
\hline 27 & $\mathrm{R} 27$ & 109.09030 & -7.65123 & 214 & Tanah Sedang & 0.445 & 1.0 & 0.445 \\
\hline 29 & $\mathrm{R} 29$ & 109.07030 & -7.68966 & 169 & Tanah Lunak & 0.450 & 0.9 & 0.405 \\
\hline 26 & $\mathrm{R} 30$ & 109.01933 & -7.74956 & 214 & Tanah Sedang & 0.468 & 1.0 & 0.468 \\
\hline 28 & $\mathrm{R} 31$ & 109.01463 & -7.68662 & 191 & Tanah Sedang & 0.460 & 1.0 & 0.460 \\
\hline 31 & $\mathrm{R} 32$ & 109.07939 & -7.68711 & 160 & Tanah Lunak & 0.450 & 0.9 & 0.405 \\
\hline 30 & R33 & 109.01896 & -7.71438 & 182 & Tanah Sedang & 0.462 & 1.0 & 0.462 \\
\hline
\end{tabular}

Tabel 4. Skala intensiatas gempabumi badan meteorologi klimatologi dan geofisika

\begin{tabular}{|c|c|c|c|}
\hline $\begin{array}{l}\text { Skala SIG } \\
\text { BMKG }\end{array}$ & Deskripsi Sederhana & Deskrispsi Rinci & PGA (gal) \\
\hline I & Tidak dirasakan (Not Felt) & $\begin{array}{l}\text { Tidak dirasakan atau dirasakan hanya oleh beberapa orang tetapi } \\
\text { terekam oleh alat. }\end{array}$ & $<2.9$ \\
\hline II & Dirasakan (Felt) & $\begin{array}{l}\text { Dirasakan oleh orang banyak tetapi tidak menimbulkan } \\
\text { kerusakan. Benda-benda ringan yang digantung bergoyang dan } \\
\text { jendela kaca bergetar. }\end{array}$ & $2.9-88$ \\
\hline III & $\begin{array}{c}\text { KERUSAKAN RINGAN (Slight } \\
\text { Damage })\end{array}$ & $\begin{array}{l}\text { Bagian non struktur bangunan mengalami kerusakan ringan, } \\
\text { seperti retak rambut pada dinding, genteng bergeser ke bawah } \\
\text { dan sebagian berjatuhan. }\end{array}$ & $89-167$ \\
\hline IV & $\begin{array}{l}\text { KERUSAKAN SEDANG } \\
\text { (Moderate Damage) }\end{array}$ & $\begin{array}{l}\text { Banyak retakan terjadi pada dinding bangunan sederhana, } \\
\text { sebagian roboh, kaca pecah. Sebagian plester dinding lepas. } \\
\text { Hampir sebagian besar genteng bergeser ke bawah atau jatuh. } \\
\text { Struktur bangunan mengalami kerusakan ringan sampai sedang. }\end{array}$ & $168-564$ \\
\hline V & $\begin{array}{c}\text { KERUSAKAN BERAT (Heavy } \\
\text { Damage) }\end{array}$ & $\begin{array}{l}\text { Sebagian besar dinding bangunan permanen roboh. Struktur } \\
\text { bangunan mengalami kerusakan berat. Rel kereta api } \\
\text { melengkung. }\end{array}$ & $>564$ \\
\hline
\end{tabular}




\section{Analisis dan Pemetaan Risiko Gempabumi (Risk) di Kota Cilacap}

Pengertian risiko bencana adalah suatu potensi kerugian yang ditimbulkan akibat suatu bencana pada suatu kawasan dan dalam kurun waktu tertentu yang dapat berupa kematian, luka, sakit, jiwa terancam, hilangnya rasa aman, mengungsi, kerusakan atau kehilangan harta, dan gangguan kegiatan masyarakat (BNPB, 2012). Dalam penelitian ini, risiko gempabumi digambarkan melalui hasil perkalian dari perhitungan bahaya $(\mathrm{H})$ dan kerentanan (V) yang dapat di formulasikan sebagai berikut 3 (Wisner et al., 2004 dalam Yulianto, 2014).

$$
R=H \times V
$$

dengan $\mathrm{R}$ adalah risiko (risk); $\mathrm{H}$ adalah bahaya (hazard); dan $\mathrm{V}$ adalah kerentanan (vulnerability).

Secara teknis, peta risiko longsor dihasilkan melalui operasi tumpang tindih antara peta bahaya dan peta kerentanan dengan menggunakan software ArcGis 10.2. Penentuan tingkat risiko gempabumi dilakukan dengan metode skoring dan dikelompokkan ke dalam 3 kelas yaitu : (i) rendah (skor $0.11-0.22$ ), (ii) sedang (skor 0.33 0.44 ), dan (iii) tinggi (skor $0.67-1.00$ ).

\section{HASIL DAN PEMBAHASAN}

\section{Bahaya Gempabumi}

Hasil klasifikasi situs tanah yang diperoleh berdasarkan $V s^{30}$ (Tabel 3) dalam penelitian ini ditampilkan dalam Gambar 2. Berdasarkan gambar tersebut terlihat bahwa persebaran jenis tanah di daerah penelitian didominasi oleh jenis tanah sedang. Adapun jenis tanah lunak berada di Desa Menganti dan Desa Karang Kandri. Untuk jenis tanah keras terdapat di Desa Tritih Kulon yang letaknya berada di bagian utara wilayah Cilacap kota. Hasil analisis ini menunjukkan suatu kesesuaian dengan hasil penelitian struktur geologi dan tektonik di daerah penelitian yang merupakan zona rendahan DAS Citanduy. Zona ini diisi oleh endapan sedimen gravitasi atau sedimen laut yang dibatasi oleh zona tinggian Nusakambangan dan Jeruk Legi dan juga sifat keteknikan di daerah penelitian yang dicirikan oleh material sangat lepas hingga agak padat (Soebowo et al., 2009). Dominasi jenis tanah sedang dan lunak di daerah penelitian ini menyebabkan daerah penelitian berpotensi untuk mengalami kerusakan saat terjadi goncangan yang diakibatkan oleh getaran gempabumi dan akan mengalami amplifikasi.

Analisis bahaya gempabumi di bagian kota Cilacap hasilnya ditunjukkan oleh nilai percepatan maksimum di permukaan tanah $\left(P G A_{M}\right)$ seperti yang disajikan pada Tabel 4. Hasil analisis bahaya gempabumi tersebut secara spasial ditunjukkan dalam Gambar 3 yang memperlihatkan bahwa seluruh bagian kota Cilacap termasuk ke dalam kelas bahaya sedang. Hal ini menunjukkan bahwa jika terjadi guncangan gempabumi maka dapat mengakibatkan kerusakan bangunan tingkat sedang di bagian kota Cilacap, seperti terjadi retakan-retakan pada dinding bangunan sederhana, plester dinding lepas, kaca pecah, dan sebagian bangunan roboh seperti pada kejadian gempabumi sebelumnya. Hal ini berpotensi untuk dapat terjadi lagi di masa yang akan datang sehingga bahaya ini perlu diantisipasi penanggulangannya.

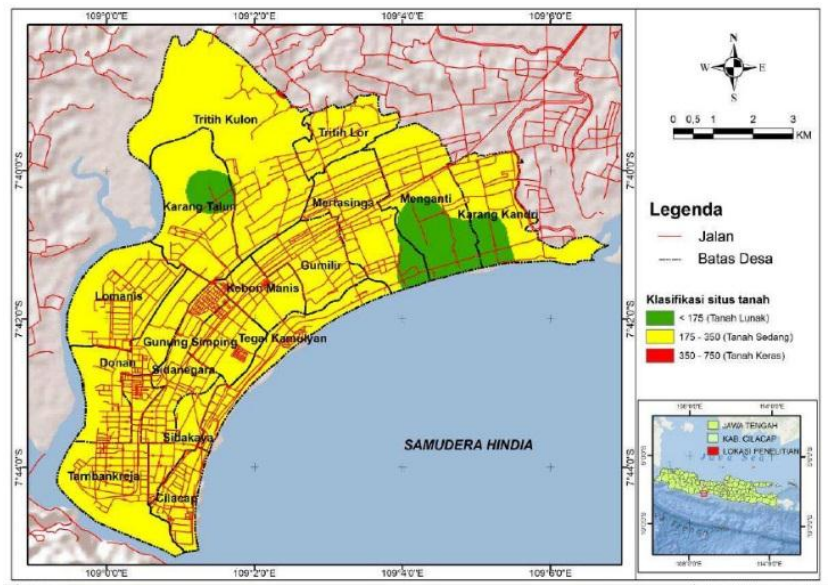

Gambar 2. Klasifikasi situs tanah Kota Cilacap Jawa Tengah berdasarkan data $V s^{30}$

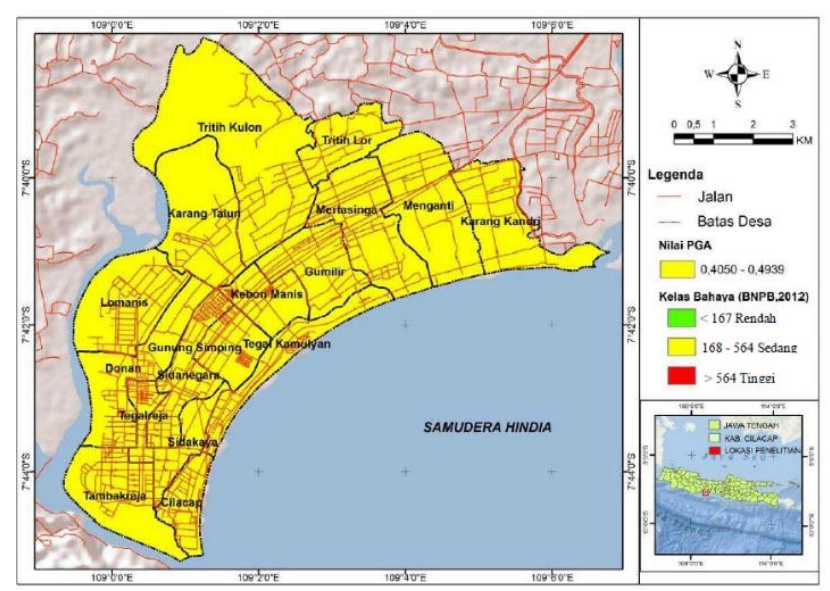

Gambar 3. Peta bahaya gempabumi Kota Cilacap Jawa Tengah

\section{Kerentanan terhadap Gempabumi}

Dari analisis kerentanan diperoleh hasil bahwa kelas kerentanan di Kota Cilacap cukup bervariasi, mulai dari kelas rendah sampai dengan kelas tinggi seperti yang ditunjukkan dalam Gambar 4. Luas kelas kerentanan rendah meliputi luasan 3,324.52 ha atau sekitar $46.52 \%$ dari total luas daerah penelitian, kerentanan sedang seluas 583.90 ha $(8.17 \%)$, dan kerentanan tinggi seluas 3,238.36 ha atau $45.31 \%$. Dalam hal ini, daerah yang memiliki tingkat kerentanan rendah berpeluang kecil mengalami kerusakan maupun jatuhnya korban jiwa. Daerah ini tersebar di kawasan-kawasan yang belum terbangun yaitu terdiri dari lahan sawah, kebun, rawa, dan lahan terbuka. Daerah dengan tingkat kerentanan sedang berpotensi mengalami kerusakan dan jatuhnya korban jiwa, namun tidak sebesar wilayah dengan tingkat kerentanan tinggi. Wilayah kerentanan sedang ini tersebar di Desa-desa Lomanis, Karang Talun, Karang Kandri, dan Tambakreja. Apabila daerah-daerah yang mempunyai tingkat kerentanan sedang ini perkembangannya kelak tidak diimbangi dengan upaya mengontrol tingkat kerentanan, maka tidak menutup kemungkinan akan berubah menjadi daerah yang memiliki tingkat kerentanan tinggi. Adapun daerah yang mempunyai tingkat kerentanan tinggi 
merupakan daerah yang berpotensi mengalami kerusakan dan jatuhnya korban jiwa. Daerah-daerah yang tergolong mempunyai tingkat kerentanan tinggi ini mencakup lahan permukiman yang terdapat di Desa-desa Tambakreja, Sidanegara, Donan, Tritih Kulon bagian selatan, Cilacap, Mertasinga, dan Kamulyan. Daerah-daerah tersebut berpotensi menjadi daerah dengan banyak korban jiwa dan bangunan (rumah) rusak apabila kelak terjadi gempabumi.

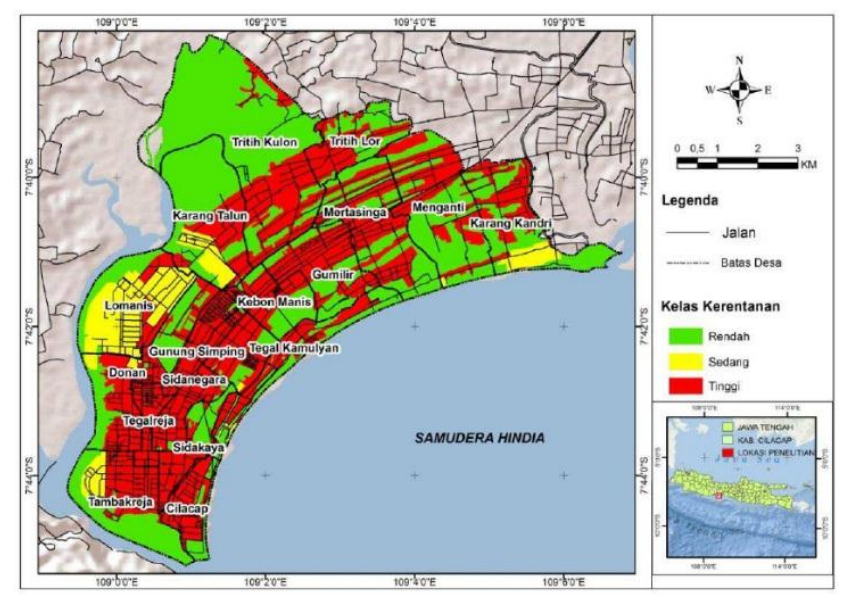

Gambar 4. Peta kerentanan gempabumi Kota Cilacap Jawa Tengah

\section{Risiko Gempabumi}

Analisis risiko gempabumi secara formulatif dapat ditentukan berdasarkan hasil perkalian antara nilai bahaya dan kerentanan. Hasil analisis risiko dalam penelitian ini disajikan pada Gambar 5. Dari gambar tersebut, daerah penelitian memiliki kelas risiko gempabumi bervariasi dari rendah sampai tinggi. Secara administrasi total luas wilayah yang memiliki kelas risiko rendah yaitu 3,357.38 ha, risiko sedang 586.04 ha, dan risiko tinggi 3,237.40 ha. Daerah penelitian yang mempunyai tingkat "risiko tinggi" terluas terdapat di Desa Tritih Kulon (327.20 ha), diikuti oleh Desa Sidanegara (310.01 ha), Tambakreja (280.84 ha), dan Cilacap (146.03 ha). Risiko tinggi ini lebih disebabkan oleh nilai bahaya sedang namun mempunyai tingkat kerentanan gempabumi yang tinggi karena wilayah-wilayah tersebut merupakan daerah permukiman dan kawasan pemerintahan yang ketahanan bangunannya terhadap gempabumi sangat rendah. Untuk tingkat risiko sedang meliputi Desa-desa Lomanis (347.91 ha), Karang Talun (85.75 ha), Karang Kandri (65.85 ha), dan Tambakreja (53.89 ha). Daerah "risiko sedang" ini merupakan kawasan industri dimana kekuatan bangunan di kawasan ini jauh lebih baik daripada bangunan permukiman sehingga berpotensi mengalami kerusakan sedang jika mengalami guncangan akibat gempabumi. Adapun untuk "risiko rendah" mencakup Desa-desa Tritih Kulon (924.62 ha), Karang Talun (360.59 ha), Menganti (356.04 ha), Karang Kandri (250.50 ha), dan Tambakreja (225.43 ha). Daerah dengan risiko rendah ini relatif aman dari bencana gempabumi karena meliputi lahan-lahan yang belum ada bangunannya dan tidak ada penduduknya. Dari semua hasil tersebut di atas, maka Desa-desa Tritih Kulon, Sidanegara, Tambakreja, dan Cilacap perlu mendapat perhatian jika terjadi gempabumi nanti karena wilayah ini berada di daerah "risiko tinggi" yang berpotensi mengalami kerusakan berat pada bangunan dan korban jiwa. Oleh sebab itu program mitigasi bencana gempabumi di wilayah ini perlu diprioritaskan untuk masa yang akan datang.

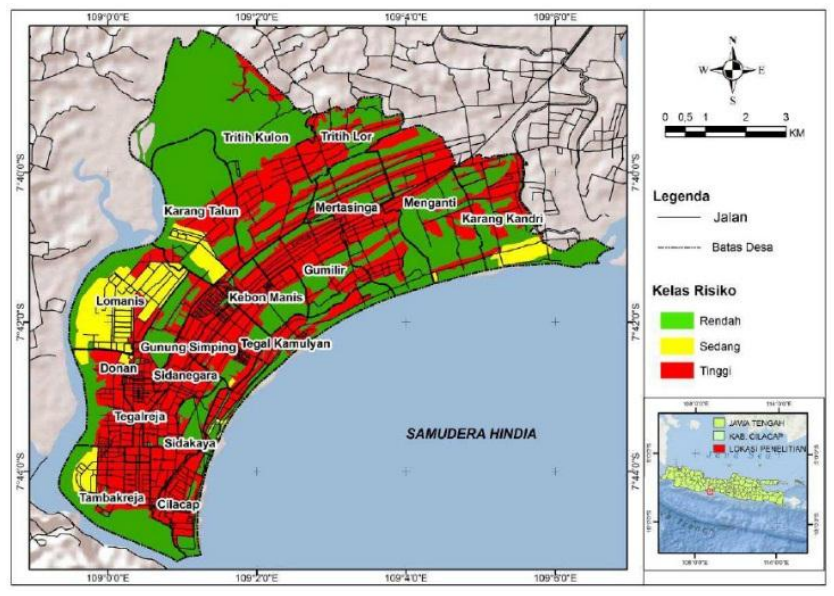

Gambar 5. Peta risiko bencana gempabumi Kota Cilacap Jawa Tengah

\section{SIMPULAN}

1. Hasil analisis bahaya gempabumi di Kota Cilacap menunjukkan bahwa seluruh Kota Cilacap tergolong ke dalam kategori tingkat "bahaya sedang". Konsekuensinya adalah dapat mengalami kerusakan sedang jika terjadi guncangan gempabumi.

2. Tingkat kerentanan daerah penelitian, bervariasi mulai dari kelas rendah sampai dengan kelas tinggi. Daerah penelitian dengan tingkat kerentanan tinggi berupa lahan permukiman yang secara administratif meliputi Desa-desa Tambakreja, Sidanegara, Donan, Tritih Kulon bagian selatan, Cilacap, Mertasinga, dan Kamulyan.

3. Wilayah yang memiliki tingkat risiko tinggi di daerah penelitian meliputi area seluas $3,237.40$ ha yang secara administratif mencakup Desa-desa Lomanis, Tambakreja, Tritih Kulon, Sidanegara, Donan, Mertasinga, dan Cilacap. Selain itu daerah penelitian didominasi oleh kelas risiko tinggi, yang disebabkan oleh tingkat kerentanan yang tinggi. Hal ini dikarenakan daerah penelitian didominasi oleh areal permukiman dan mempunyai tanah lunak (lepas-lepas), sehingga harus mendapat perhatian besar untuk mitigasi bencana gempabumi di masa yang akan datang.

\section{DAFTAR PUSTAKA}

[BMKG] Badan Meteorologi Klimatologi dan Geofisika. 2009. Laporan Gempabumi Dirasakan 2009. Badan Meteorologi Klimatologi dan Geofisika, Jakarta.

[BMKG] Badan Meteorologi Klimatologi dan Geofisika. 2015. Katalog Gempabumi Signifikan dan Merusak. Badan Meteorologi Klimatologi dan Geofisika, Jakarta. 
[BNPB] Badan Nasional Penanggulangan Bencana. 2009. Laporan Harian Pusdalops BNPB 6 September 2009.

www.bnpb.go.id/uploads/migration/pubs/337.pdf.

[BNPB] Badan Nasional Penanggulangan Bencana. 2012. Pedoman Umum Pengkajian Risiko Bencana. Peraturan Kepala BNPB Nomor 02 Tahun 2012.

[BPS] Badan Pusat Statistik Kabupaten Cilacap. 2014. Kecamatan Dalam Angka Tahun 2014. https://cilacapkab.bps.go.id/index.php/Publikasi.

[BSN] Badan Standardisasi Nasional. 2012. Tata Cara Perencanaan Ketahanan Gempabumi untuk Struktur Bangunan Gedung dan Non-Gedung (SNI 1726-2012).

Cardona, O.D., M.K. van Aalst, J. Birkmann, M. Fordham, G. McGregor, R. Perez, R.S. Pulwarty, E.L.F. Schipper, and B.T. Sinh. 2012. Determinants of risk: exposure and vulnerability. In C.B. Field, V. Barros, T.F. Stocker, D. Qin, D.J. Dokken, K.L. Ebi, M.D. Mastrandrea, K.J. Mach, G.K. Plattner, S.K. Allen, M. Tignor, and P.M. Midgley (Eds.). Managing the Risks of Extreme Events and Disasters to Advance Climate Change Adaptation. A Special Report of Working Groups I and II of the Intergovernmental Panel on Climate Change (IPCC). Cambridge University Press, Cambridge, UK, and New York, NY, USA, p. 65-108.

Djuri, M. 1975. Peta Geologi Lembar Purwokweto dan Tegal, Jawa. Lembar 10/XIV-C dan 10/XIII-F Skala 1: 100.000. Direktorat Geologi, Direktorat Jendral Pertambangan Umum, Departemen Pertambangan.

Hadisumarno, S., S. Martopo, and Sutanto. 1982. Remote sensing of geographical features of the Cilacap Region. In Proceedings of the Workshop on Coastal Resources Management in Cilacap Region, 20-24 August 1980. Gadjah Mada University, Yogyakarta. p. 17-22.

McGuire, R.K. 1995. Probabilistic seismic hazard analysis and design earthquakes: closing the loop. Bulletin of the Seismological Society of America, 85: 12751284.
Mualchin, L. 2011. History of modern earthquake hazard mapping and assessment in California using a deterministic or scenario approach. Pure Appl. Geophys., 168: 383-407.

Nguyen N., J. Griffin, A. Cipta, and P.R. Cummins. 2015. Indonesia's Historical Earthquake: Modelled Examples for Improving the National Hazard Map. Geoscience Australia. Australian Government. p. 79.

Soebowo, E., A. Tohari, Y. Kumoro, dan M.R. Daryono 2009. Sifat keteknikan bawah permukaan di daerah pesisir Cilacap, Provinsi Jawa Tengah. Buletin Geologi Tata Lingkungan, 19: 59-66.

Sokolov, V. dan A. Ismail-Zadeh. 2015. Seismic hazard from instrumentally recorded, historical and simulated earthquakes: application to the TibetHimalayan region. Tectonophysics, 657: 187-204.

Sunardi, B. dan J. Nugraha. 2015. Percepatan tanah maksimum di permukaan dan spektra percepatan untuk Kota Makassar berdasarkan pendekatan probabilistik. Jurnal Meteorologi dan Geofisika, 10: 57-64.

Verstappen, H. 2000. Outline of the Geomorphology of Indonesia: A Case Study on Tropical Geomorphology of a Tectogene Origin. ITC Publication number 79. Enschede. The Netherlands. p. 212.

Wang Z., E.W. Woolery, B. Shi, and J.D. Kiefer. 2003. Communicating with uncertainty: A critical issue with probabilistic seismic hazard analysis. Eos., 84: 501-508.

Wang, Z. 2012. Comment on "PSHA validated by quasi observational means" by R.M.W. Musson. Seismological Research Letters, 83: 714-716.

Yulianto, F. 2014. Analisis risiko aliran piroklastik gunungapi merapi pasca erupsi 2010 menggunakan data penginderaan jauh dan sistem informasi geografis [Tesis]. IPB. Bogor. 